ДЕМ'ЯНЧИК В.В.

\title{
АНАЛІЗ ЕФЕКТИВНОСТІ АДМІНІСТРАТИВНОГО ДЕЛЕГУВАННЯ ФУНКЦЙ, ПРИТАМАННИХ ОРГАНАМ ТА УСТАНОВАМ ВИКОНАННЯ ПОКАРАНЬ, МІНІСТЕРСТВУ ЮСТИЦІЇ УКРАЇНИ
}

Стаття присвячена аналізу стану реформування пенітенціарної системи України в питанні делегування правозастосовної та правоохоронної функції держави Міністерству юстиції України. Підтримана Урядом реформа пенітенціарної системи України шляхом ліквідації ДПтС та передання ії повноважень і функцій до Міністерства. Виконання цих заходів мало за мету залучити нових людей через відкриті конкурси, демілітаризувати систему, скоротити значну чисельність персоналу та підвищити заробітну плату, забезпечити належні умови перебування в пенітенціарних установах. Станом на сьогодні центральним органом виконавчої влади, що реалізує державну політику у сфері виконання кримінальних покарань, $€$ Міністерство юстиції України.

3 метою виконання вказаних завдань і функцій у структурі Міністерства юстиції діє Державна кримінально-виконавча служба України.

При цьому необхідно звернути увагу на те, що Державна кримінально-виконавча служба України виконує притаманні тільки їй функції виправлення і ресоціалізації засуджених, правоохоронну функцію, а також функції охорони здоров'я, навчання, наділена правом займатись оперативно-розшуковою діяльністю, має у своєму підпорядкуванні воєнізовані формування, зброю, виробничі потужності промислового та сільськогосподарського призначення.

Відповідно до положень Закону України «Про Державну кримінально-виконавчу службу України» можна констатувати, що законодавець передбачив для служби тільки дві функції - правозастосовну та правоохоронну.

Водночас на Міністерство юстиції покладено забезпечення утримання новостворених державних установ у межах наявної чисельності органів і установ Державної кримінально-виконавчої служби та видатків, що передбачені на їх утримання в Державному бюджеті України на відповідний рік.

Зокрема, відповідно до оптимізації структури Міністерства юстиції України для виконання правозастосовчої та правоохоронної функцій, які не властиві Мін'юсту, в системі виконання покарань були створені три відомства: «Адміністрація державної кримінально-виконавчої служби», «Центр пробації» і «Центр охорони здоров'я».

Ключові слова: Міністерство юстиції Украӥни, кримінально-виконавча служба, адміністрація, Центр пробації, Центр охорони здоров'я.

The article is devoted to the analysis of the state of reform of the penitentiary system of Ukraine in the matter of delegation of law enforcement and law enforcement function of the state by the Ministry of Justice of Ukraine. The Government supported the reform of Ukraine's penitentiary system by eliminating the SPS and transferring its powers and functions to the Ministry. The implementation of these measures was aimed at attracting new people through open competitions, demilitarizing the system, reducing the significant number of staff and increasing salaries, and ensuring proper conditions of stay in penitentiary institutions. At present, the Ministry of Justice of Ukraine is the central executive body implementing state policy in the area of criminal penalties.

The State Criminal Enforcement Service of Ukraine operates in the structure of the Ministry of Justice to fulfill these tasks and functions.

(С) ДЕМ'ЯНЧИК В.В. - аспірант кафедри державно-правових дисциплін та адміністративного права (Центральноукраїнський державний педагогічний університет імені Володимира Винниченка) 
It should be noted that the State Penitentiary Service of Ukraine performs its inherent functions of correction and re-socialization of convicts, law enforcement function, as well as health care functions, training, empowered to engage in operational and search activities, has subordination militarized formations, weapons, industrial and agricultural production facilities.

According to the provisions of the Law of Ukraine "On the State Criminal Enforcement Service of Ukraine", it can be stated that the legislator provided for the service only two functions - law enforcement and law enforcement.

At the same time, the Ministry of Justice is responsible for maintaining the newly established state institutions within the existing number of bodies and institutions of the State Penal Enforcement Service and the expenditures provided for their maintenance in the State Budget of Ukraine for the respective year.

In particular, according to the optimization of the structure of the Ministry of Justice of Ukraine for performing law enforcement and law enforcement functions that are not peculiar to the Ministry of Justice, three departments were created in the system of punishment execution: "Administration of the State Criminal Enforcement Service", "Probation Center" and "Health Care Center.

Key words: Ministry of Justice of Ukraine, criminal enforcement service, administration, Probation Center, Health Center.

Вступ. Запроваджена за ініціативою Міністерства юстиції України та підтримана Урядом реформа передбачала створення нової пенітенціарної системи в Україні. Розроблена Міністерством юстиції України Концепція реформування (розвитку) пенітенціарної системи України мала своїм завданням: залучення нових кадрів у систему на всіх рівнях; розроблення законодавства у сфері функціонування слідчих ізоляторів та установ виконання покарань відповідно до законодавства Європейського Союзу; підвищення операційної ефективності державних підприємств у пенітенціарній системі; будівництво нових слідчих ізоляторів та установ виконання покарань. Тому актуальним є розгляд ефективності реформування в питанні делегування функцій, притаманних органам та установам виконання покарань у структурі Міністерства юстиції України.

Проблеми регулювання управління та реформування в системі виконання покарань досліджували Є.Ю. Бараш, С.К. Гречанюк, В.Ф. Пузирний, В.І. Селіверстов, В.Г. Хирний, С. Зливко та інші.

Постановка завдання. Мета дослідження - грунтовний аналіз ефективності адміністративного делегування та нормативного забезпечення у сфері виконання функцій, притаманних органам та установам виконання покарань Міністерством юстиції України.

Результати дослідження. Розпорядженням Кабінету Міністрів України від 22.09.2016 p. № 697-р на Міністерство юстиції України були покладені завдання і функції з реалізації державної політики у сфері виконання кримінальних покарань та пробації [7].

3 метою виконання вказаних завдань і функцій у структурі Міністерства юстиції діє Державна кримінально-виконавча служба України.

Правовою основою діяльності Державної кримінально-виконавчої служби України є Конституція України, закони України «Про Державну кримінально-виконавчу службу України», «Про чисельність Державної кримінально-виконавчої служби України», Кримінальний, Кримінальний процесуальний, Кримінально-виконавчий кодекси України, інші нормативно-правові акти [1].

Головним, можна його назвати статусним, $є$ Закон України «Про Державну кримінально-виконавчу службу України» від 23.06.2005 р. № 2713, який визначає правові основи організації та діяльності Державної кримінально-виконавчої служби України, іiї завдання та повноваження [4, c. 130].

Відповідно до ст. 1 Закону на Державну кримінально-виконавчу службу України покладається завдання щодо здійснення державної політики у сфері виконання кримінальних покарань.

При цьому необхідно звернути увагу на те, що Державна кримінально-виконавча служба України виконує унікальну й притаманну тільки їй функцію виправлення і ресоціалізації засуджених, правоохоронну функцію, а також функції охорони здоров'я, загальноосвітнього та професійно-технічного навчання, наділена правом займатись оперативно-розшуковою діяльністю, має у своєму підпорядкуванні воєнізовані формування, зброю, виробничі потужності промислового та сільськогосподарського призначення [4, с. 130-131].

Проте, якщо звернутися до положень Закону України «Про Державну кримінально-виконавчу службу України», то можна констатувати, що законодавець передбачив для служби тільки дві функції - правозастосовну та правоохоронну [4, с. 131]. 
Зокрема, відповідно до оптимізації структури Міністерства юстиції України для виконання правозастосовчої та правоохоронної функцій, які не властиві Мін'юсту, в системі виконання покарань були створені три відомства: «Адміністрація державної кримінально-виконавчої служби», «Центр пробації» і «Центр охорони здоров’я» [4, с. 130].

Отже, нині згідно з п. 1 Положення про Міністерство юстиції України, затвердженого постановою Кабінету Міністрів України від 02.07.2014 р. № 228, Мін’юст є головним органом у системі центральних органів виконавчої влади, що забезпечує формування та реалізує державну політику у сфері виконання кримінальних покарань та пробації [1].

Згідно з вимогами п. 3 Положення, основними завданнями Мін'юсту, зокрема, є:

- забезпечення формування та реалізація державної політики у сфері виконання кримінальних покарань та пробації;

- забезпечення формування системи наглядових, соціальних, виховних та профілактичних заходів, які застосовуються до засуджених та осіб, узятих під варту;

- контроль за дотриманням прав людини і громадянина, вимог законодавства щодо виконання і відбування кримінальних покарань, реалізацією законних прав та інтересів засуджених та осіб, узятих під варту [1].

Відповідно до ч. 1 ст. 14 Закону України «Про Державну кримінально-виконавчу службу України» до персоналу Державної кримінально-виконавчої служби України належать особи рядового і начальницького складу (далі - особи рядового і начальницького складу кримінально-виконавчої служби), спеціалісти, які не мають спеціальних звань, та інші працівники, які працюють за трудовими договорами в Державній кримінально-виконавчій службі України (далі - працівники кримінально-виконавчої служби). Особам рядового і начальницького складу встановлюються спеціальні звання, перелік яких визначено ч. 6 ст. 14 Закону України «Про Державну кримінально-виконавчу службу України» [3].

На спеціалістів Державної кримінально-виконавчої служби України, які не мають спеціальних звань, поширюється дія Закону України «Про державну службу». Зарахування посад цих спеціалістів до відповідних категорій посад державних службовців проводиться Кабінетом Міністрів України [3].

На осіб рядового і начальницького складу Державної кримінально-виконавчої служби України поширюються вимоги та обмеження, встановлені Законом України «Про засади запобігання і протидії корупції» [3].

Згідно із ч. 5 ст. 21 Закону України «Про Державну кримінально-виконавчу службу України» особи рядового і начальницького складу кримінально-виконавчої служби мають право на носіння форменого одягу із знаками розрізнення, зразки якого розробляються відповідно до законодавства [3].

До 25.12.2015 р. була чинною постанова Кабінету Міністрів України від 17.07.2003 p. № 1073 «Про затвердження зразків форми одягу і знаків розрізнення військовослужбовців Збройних сил, інших військових формувань, Державної спеціальної служби транспорту, осіб рядового і начальницького складу Державної кримінально-виконавчої служби та ліцеїстів військових ліцеїв і ліцеїв з посиленою військово-фізичною підготовкою» [1].

325.12 .2015 р. вказане рішення Уряду втратило чинність згідно із постановою Кабінету Міністрів України від 16.12.2015 р. № 1059 «Про визнання такими, що втратили чинність, деяких постанов Кабінету Міністрів України». Проте нормативно-правового акта, який би визначав зразки форми одягу і знаки розрізнення для осіб рядового і начальницького складу Державної кримінально-виконавчої служби України, немає [1].

Встановлено, що з ліквідацією Державної пенітенціарної служби України система управління органами і установами Державної кримінально-виконавчої служби України (далі - органи й установи) кардинально змінилася. Замість єдиного структурного підрозділу, який здійснював управління органами і установами, а саме центрального апарату Державної пенітенціарної служби України, в апараті Мін'юсту було утворено кілька самостійних структурних підрозділів (рис. 1).

Змінилася й структура територіальних органів управління кримінально-виконавчої служби. Замість ліквідованих 24 управлінь ДПтС утворено шість міжрегіональних управлінь із питань виконання кримінальних покарань та пробації Мін'юсту (далі - міжрегіональні управління), а саме: Центральне (м. Київ), Центрально-Західне (м. Вінниця), Західне (м. Львів), Північно-Східне (м. Харків), Південне (м. Одеса) і Південно-Східне (м. Дніпро) міжрегіональні управління [1].

Внаслідок цих змін загальна штатна чисельність структурних підрозділів апарату Мін'юсту, на які покладені функції управління, контролю та забезпечення діяльності органів і установ 

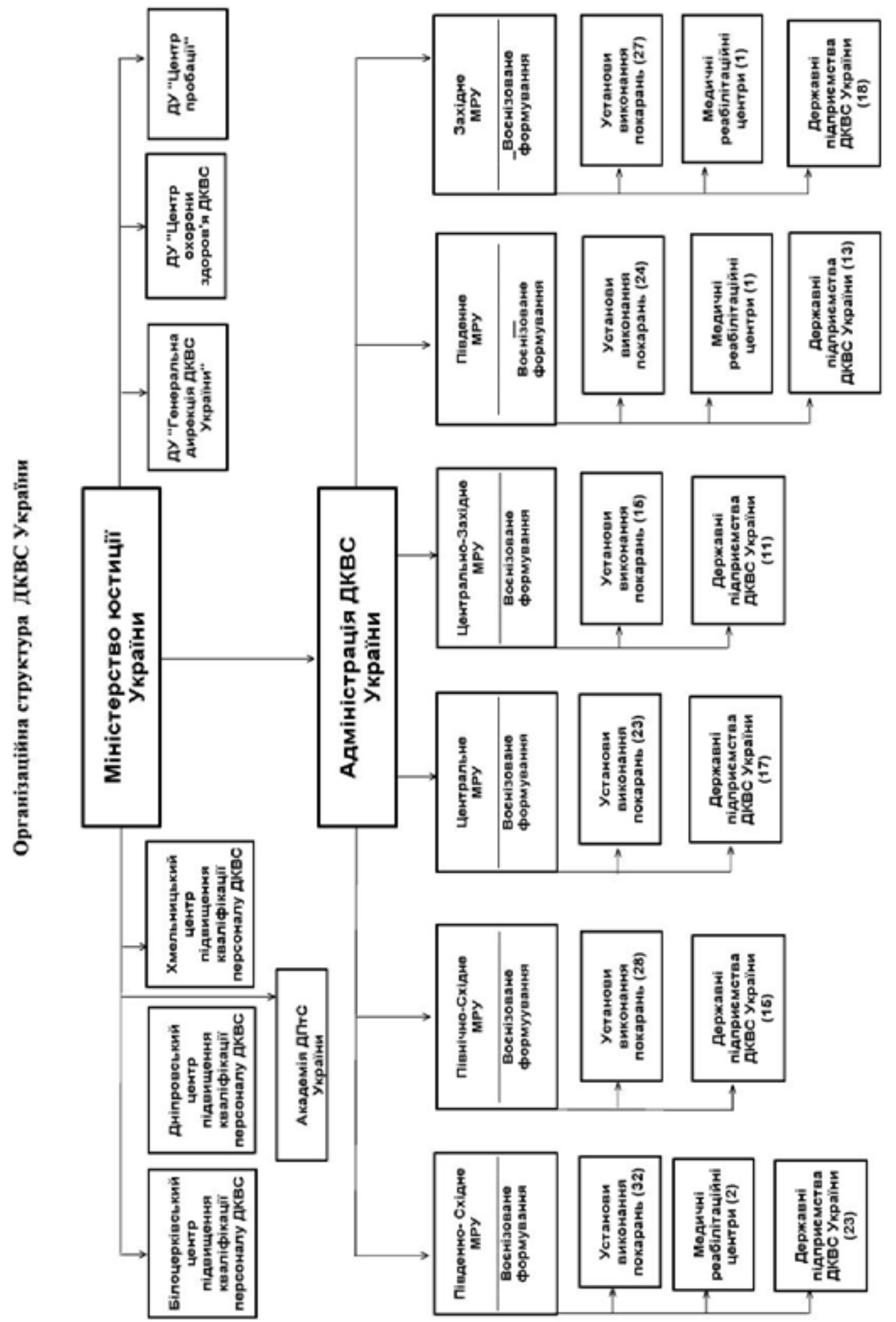


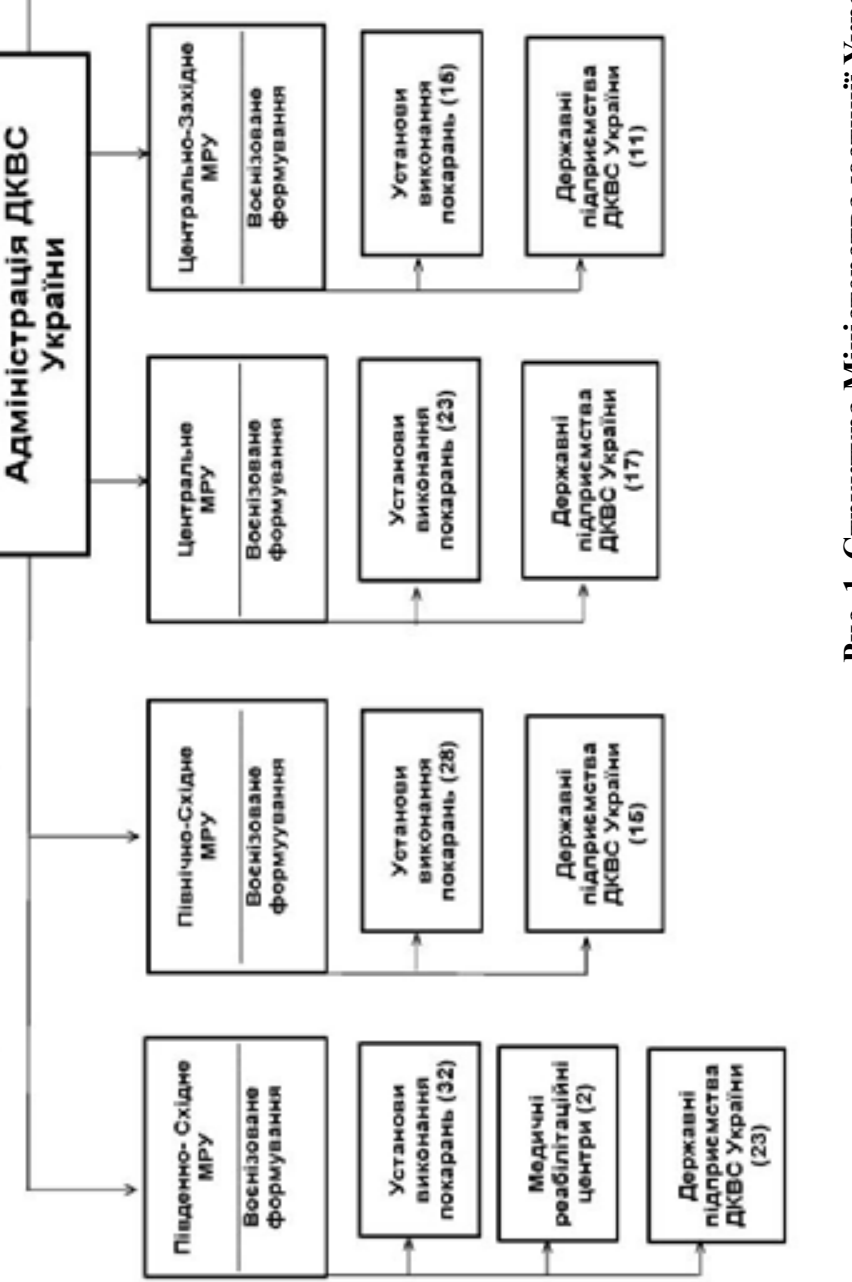
(кожен за своїм напрямом), порівняно з чисельністю центрального апарату ДПтС, зменшилась з 300 до 172 одиниць, територіальних органів управління - 1286 до 730 одиниць [1].

Як вбачається з положень про структурні підрозділи апарату Мін'юсту, кожен із них здійснює керівництво та контроль за діяльністю органів і установ Державної кримінально-виконавчої служби України окремо за своїм напрямом.

Постановою Кабінету Міністрів України № 709 від 13.09.2017 р. було утворено як юридичну особу публічного права міжрегіональний територіальний орган Міністерства юстиції з питань виконання кримінальних покарань - Адміністрацію Державної кримінально-виконавчої служби України [8].

Створення Адміністрації Державної кримінально-виконавчої служби України зумовлене, насамперед, необхідністю позбавлення апарату Мін'юсту правоохоронних функцій, оскільки наведені повноваження Адміністрації Державної кримінально-виконавчої служби мають виконуватись атестованим персоналом - особами рядового і начальницького складу Державної кримінально-виконавчої служби [2].

Проте планувалося, що слідчі підрозділи Державної кримінально-виконавчої служби будуть залишені в апараті Мін'юсту, що дасть змогу забезпечити процесуальну незалежність слідчих та уникнути впливу на процес досудового розслідування керівників та персоналу органів $\mathrm{i}$ установ Державної кримінально-виконавчої служби [2].

Рішенням Конституційного суду України № 3-р/2018 від 24.04.2018 р. функціонування в апараті Мін'юсту слідчих органів Державної кримінально-виконавчої служби України, які здійснювали б досудове розслідування злочинів, вчинених на території або в приміщеннях Державної кримінально-виконавчої служби України, визнано таким, що не відповідає Конституції України [6].

3 метою створення повноцінної системи пробації, здатної забезпечити баланс між безпекою суспільства, запобігання злочинам та запобігання скоєнню злочинів/реабілітації правопорушників, пропонується ліквідувати Департамент пробації Мін'юсту, структурні підрозділи 3 питань пробації міжрегіональних управлінь та утворити єдину державну установу «Центр пробації» 3 підпорядкуванням їй уповноважених органів із питань пробації, що дасть змогу удосконалити організаційну структуру, механізм використання фінансових, матеріальних та технічних умов функціонування органів пробації для ефективного використання поставлених завдань.

Розпорядженням Кабінету Міністрів України № 655-р від 13.09.2017 р. було утворено з 1 січня 2018 р. державної установи «Центр пробації» [9].

3 метою вдосконалення кадрового, фінансового та матеріально-технічного забезпечення системи охорони здоров'я Державної кримінально-виконавчої служби, поліпшення умов тримання засуджених та осіб, узятих під варту, в установах виконання покарань Мін'юст планує утворити державну установу «Центр охорони здоров'я Державної кримінально-виконавчої служби», що дасть змогу забезпечити здійснення реформи медичної служби пенітенціарних закладів та зробити лікаря незалежним від керівника установи виконання покарань, що, насамперед, забезпечить неупереджене встановлення діагнозу та якісне надання медичної допомоги.

Розпорядженням Кабінету Міністрів України № 684-р від 13.09.2017 р. було утворено з 1 листопада 2017 р. державної установи «Центр охорони здоров’я Державної кримінально-виконавчої служби України» [10].

Водночас на Міністерство юстиції покладено забезпечення утримання новостворених державних установ у межах наявної чисельності органів і установ Державної кримінальновиконавчої служби та видатків, що передбачені на їх утримання в Державному бюджеті України на відповідний рік.

Висновки. Як наслідок, незважаючи на те, що з часу прийняття рішення про ліквідацію Державної пенітенціарної служби України минув значний час, комплектування Міністерства юстиції триває.

Наявна у сфері виконання кримінальних покарань та пробації нормативно-правова база 3 урахуванням прийнятих останнім часом урядових рішень потребує додаткового правового врегулювання, а саме:

1) прийняття Закону України «Про пенітенціарну систему» [5], яким би врегульовувалися питання оптимізації структури пенітенціарної системи, спрощення управління сукупністю іiі підрозділів, що дало б змогу зробити її більш гнучкою, оперативною, дієвою, впровадити нові підходи до заохочення ії̈ персоналу, запровадити ефективне управління підприємствами установ 
виконання покарань. Після прийняття зазначеного Закону потребуватимуть узгодження 3 ним нормативно-правові акти Кабінету Міністрів України та Мін'юсту;

2) вжиття заходів щодо оптимізації структури органів Державної кримінально-виконавчої служби, системи функціонування установ виконання покарань та слідчих ізоляторів, штатної чисельності персоналу зазначеної Служби та підвищення ефективності його діяльності в умовах реалізації нової політики державного управління.

\section{Список використаних джерел:}

1. Звіт Рахункової Палати про результати аудиту ефективності використання Міністерством юстиції України бюджетних коштів, виділених на забезпечення функцій у сфері виконання кримінальних покарані та пробації від 27.06.2017 p. № 13-3. URL: https://rp.gov.ua’upload-files' Activity'Collegium'Zvit_13-3_2017.

2. Про схвалення Концепції реформування (розвитку) пенітенціарної системи України : розпорядження Кабінету Міністрів України від 13.09.2017 р. № 654-p. URL: https://zakon.rada.gov.ua/laws/show/654-2017-\%D1\%80\#n11.

3. Про Державну кримінально-виконавчу службу України : Закон України від 23.06.2005 p. № 2713-IV. URL: https://zakon.rada.gov.ua/laws/show/2713-15.

4. Зливко С.В. Аналіз нормативно-правових актів щодо регулювання діяльності керівника в системі виконання покарань. Підприємство господарство і право. 2018. № 4. С. 130-134.

5. Проект Закону про пенітенціарну систему від 24.11.2017 p. № 7337 . URL: http://w1.c1.rada.gov.ua/pls/zweb2/webproc4_1?pf3511=62965.

6. Рішення Конституційного суду України у справі за конституційним поданням Уповноваженого Верховної Ради України 3 прав людини щодо відповідності Конституції України (конституційності) частини шостої статті 216 Кримінального процесуального кодексу України № 3-p/2018 від. 28.04.2018 p. URL: https://zakon.rada.gov.ua/laws/show/v003p710-18.

7. Питання Міністерства юстиції: Розпорядження Кабінету Міністрів України № 697-р від 22.09.2016 p. URL: https://zakon.rada.gov.ua/laws/show/697-2016-\%D1\%80.

8. Про утворення міжрегіонального територіального органу Міністерства юстиції з питань виконання кримінальних покарань : Постанова Кабінету Міністрів України № 709 від 13.09.2017 p. URL: https://zakon.rada.gov.ua/laws/show/709-2017-\%D0\%BF.

9. Про утворення державної установи «Центр пробації» : Постанова Кабінету Міністрів України № 655-р від 13.09.2017 p. URL: https://zakon.rada.gov.ua/laws/show/655-2017-\%D1\%80.

10. Про утворення державної установи «Центр охорони здоров’я Державної кримінально-виконавчої служби України»: Постанова Кабінету Міністрів України № 655-р від 13.09.2017 p. URL: https://zakon.rada.gov.ua/laws/show/684-2017-\%D1\%80. 